\title{
Migratory Seasonality and Phenology by Birds in a Temperate Forest with Two Disturbance Conditions
}

\author{
Cruz-Miranda, Yessenia ${ }^{1}$; Tarango-Arámbula, Luis A. ${ }^{1}$; Escobar-Flores, Jonathan G. ${ }^{2^{*}}$; \\ Olmos-Oropeza, Genaro $^{1}$; Chapa-Vargas, Leonardo ${ }^{3}$
}

${ }^{1}$ Colegio de Postgraduados, Campus San Luis Potosí, Postgrado de Innovación en Manejo de Recursos Naturales. Iturbide 73, Colonia Centro, Salinas de Hidalgo, San Luis Potosí, México. CP 78620.

2 Instituto Politécnico Nacional, CIIDIR Unidad Durango, Sigma 119, Fraccionamiento 20 de noviembre II, Durango, 34220, Durango, México.

${ }^{3}$ Instituto Potosino de Investigación Científica y Tecnológica, A.C. División de Ciencias Ambientales, Camino a la Presa San José 2055, Colonia Lomas 4a Sección, C.P. 78216, San Luis Potosí, México.

*Corresponding author: jescobarf@ipn.mx

\begin{abstract}
Objective: The objective was to infer the effect of the variables phenology (migration-non-migration), seasonality (rainfall-dry season), sex and forest condition on the abundances of birds (resident-migratory) in a semi-preserved and disturbed oak pine forest.

Design/Methodology/Approach: The study was carried out in Monte Tlaloc, Estado de México, in two conditions of apparent disturbance, semi-preserved oak pine forest and disturbed oak pine forest. Ten bird samplings were carried out with "count on point" with a fixed radius of $25 \mathrm{~m}$, covering the 4 seasons of the year and migratory periods. With this data, the Relative Abundance Index (RAI) was estimated. Generalized linear models were elaborated to infer the effect of the variables phenology, seasonality, sex, and forest condition on the abundances of birds.

Results: The RAI of the birds registered in the semi-considered pine forest indicates that the species with the lowest presence was Aphelocoma ultramarina (0.002) and with the highest frequency Empidonax sp. (0.13), unlike to that found in the disturbed pine forest where the lowest RAI corresponded to Colaptes auratus (0.003) and Ptiliogonys cinereus (0.23) had the highest appearance. The Generalized Linear Model suggested that forest condition and phenology are significantly related to the frequency of species.

Study Limitations/Implications: In this study it was found that the abundance of birds was affected by the condition of the forest and that the phenology (migration-non-migration), seasonality (rain-dry season), sex and condition of the forest were related to the abundance of birds. Four species classified as under Special Protection and two Threatened according to NOM-059 were registered as well as the presence of four endemic species which highlights the importance of conserving these ecosystems.

Findings/Conclusions: The fauna communities present in Monte Tláloc highlight the importance of conserving the pine-oak forests since this site is part of the Trans-Mexican Volcanic Belt.
\end{abstract}

Citation: Cruz-Miranda, Yessenia, Tarango-Arámbula, Luis A., EscobarFlores, Jonathan G., Olmos-Oropeza, Genaro, \& Chapa-Vargas, Leonardo. (2021). Migratory Seasonality and Phenology by Birds in a Temperate Forest with Two Disturbance Conditions. Agro Productividad, 14(\#). https://doi. org/10.32854/agrop.v14i6.2061

Editor in Chief: Dr. Jorge Cadena Iñiguez

Estimated publication date: July 2021

This work is licensed under a Creative Commons Attribution-NonCommercial 4.0 International license

Keywords: Indices, generalized linear model, disturbed, semi-conserved.

\section{INTRODUCTION}

Phenomena such as migratory seasonality and phenology in birds have allowed understanding their population dynamics in some regions of the world, since approximately half of the species of birds perform migratory movements (Cueto et al., 2015), coexisting with the resident avifauna on the routes and corridors that they use. However, the possible coexistence between migratory and resident birds seems to be regulated, among other factors, by the quantity, quality and availability of resources in the habitat, including those that are vital and/or limiting in it, and affecting their tolerance (Shelford, 1913; Odum and Warren, 2006). In Mexico, deforestation, lossfragmentation of their habitats, change of land use, and wildfires, among others, 
have progressively affected the plant physiognomy, creating a broad heterogeneity of ecological niches (Almazán-Núñez et al., 2009). This heterogeneity can result in spacetime fluctuations or in positive, negative or null ecological interactions for generalist, specialist and flexible species, respectively, particularly of avifauna (Díaz-Bohórquez et al., 2014; López-Segoviano et al., 2019).

Monte Tláloc is located in Estado de México on the Trans-Mexican Volcanic Belt (TVB). The TVB is considered as one of the most important centers of endemism in the country and a priority terrestrial region (Bolaños-González et al., 2017), which is important seasonally and in phenology for avifauna in general; and, in particular, for migratory avifauna because it is distributed on one of the main migration routes in the American Continent, the Central. In this route, presumably their assemblages converge at different space-time scales in the use of the habitat (Romero-Díaz et al., 2018). In Monte Tláloc, the birds have chief ecological functions, for example as biological controllers or seed dispersers. Therefore, it is relevant to evaluate phenology (migration-non-migration) and seasonality (rainfed-dry) of the use of the habitat by birds (resident-migratory), in two disturbance conditions of semi-conserved pine-oak forest vs disturbed pine-oak forest.

\section{MATERIALS AND METHODS}

The study was carried out in the orography system known locally as Monte Tláloc, site dominated by mixed conifer forests. It is located in the limits of Ixtapaluca and Texcoco, in east Estado de México between coordinates $19^{\circ} 24^{\prime} 44^{\prime \prime}$ Latitude North and $98^{\circ} 42^{\prime}$ 45” Longitude West, and maximum elevation of 4120 masl (Villanueva-Díaz et al., 2016; Figure 1).

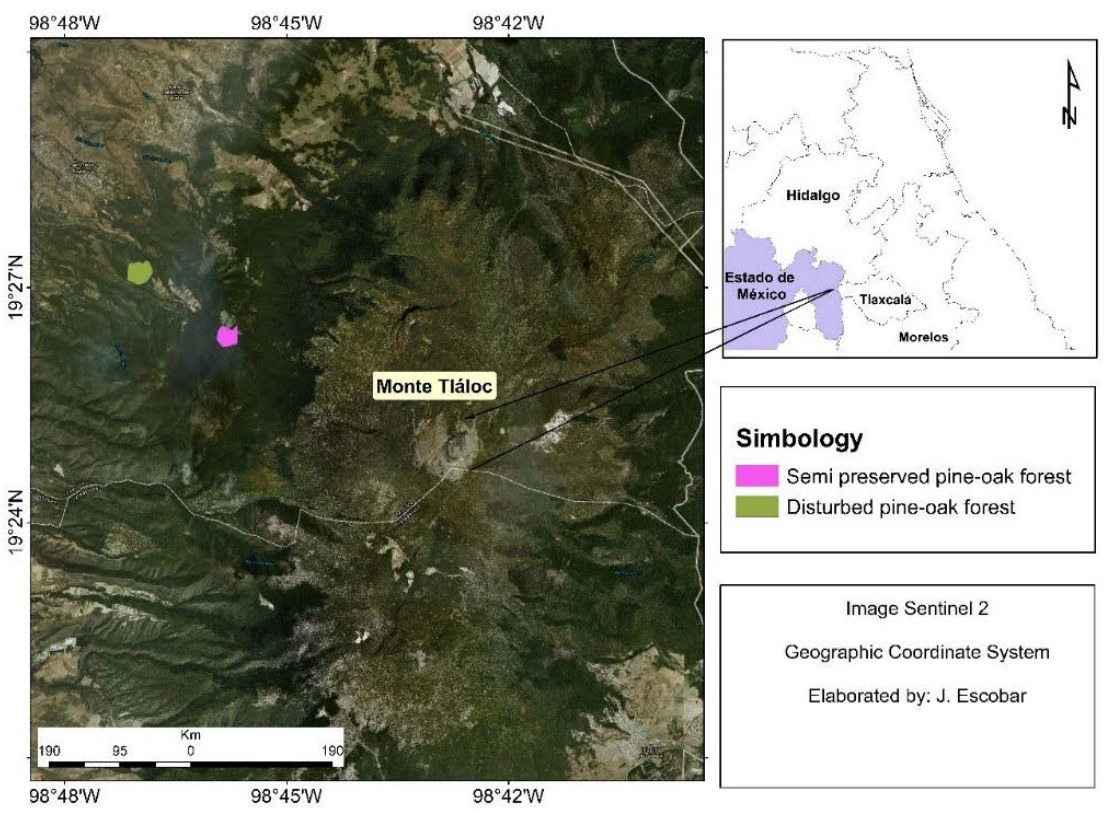

Figure 1. Location map of the study area, Monte Tláloc. 


\section{Sample design}

A systematic sampling was implemented, contemplating two apparent disturbance conditions, selected according to Romero-Díaz et al., (2018): 1) semi-conserved pineoak forest (CPOF), which was characterized by presenting a tree, shrub and herb cover in its totality, native vegetation, and presence of water bodies; and 2) disturbed pineoak forest (DPOF) that was characterized by having sites of secondary and introduced vegetation, open areas without plant cover, presence of livestock and feral animals (Figure 2). Each condition had 11 choice units with pre-determined distances of $200 \mathrm{~m}$ between them (Ralph et al., 1996).

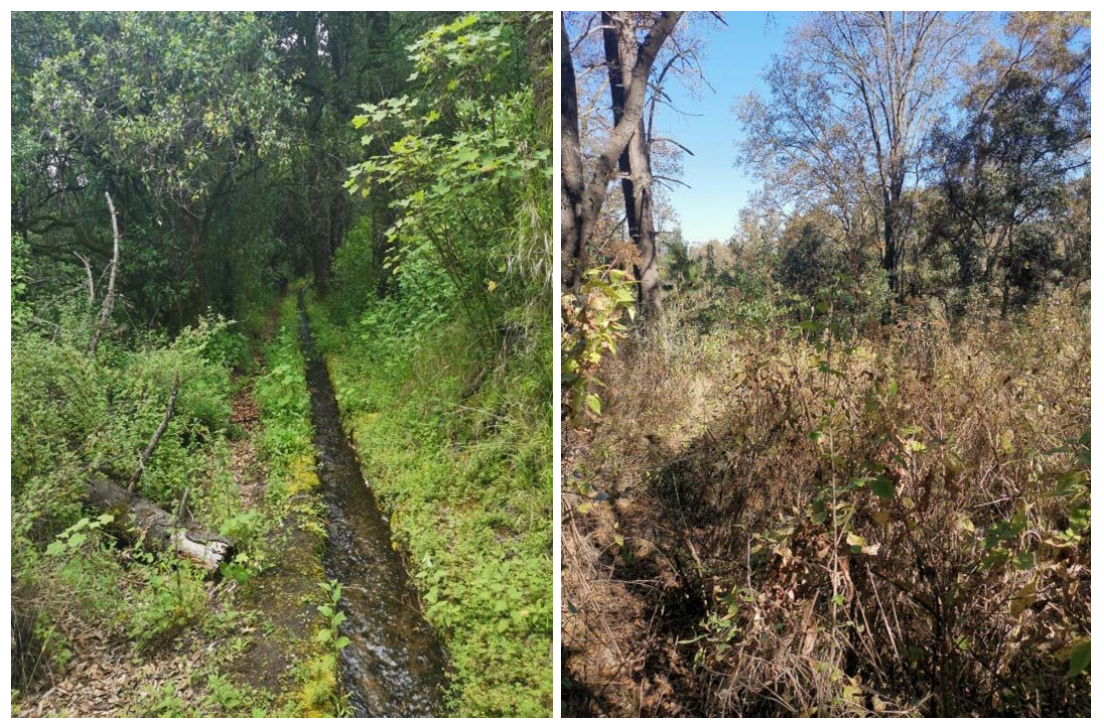

Figure 2. Image of a semi-preserved pine-oak forest (left) and a disturbed pine-oak forest (right).

\section{Bird monitoring}

From September 2019 to June 2020, monthly bird monitoring is carried out in the two conditions, CPOF and DPOF. These are carried out through the Recount scheme in a fixed radius point of $25 \mathrm{~m}$ with intensive search. The observations were carried out with binoculars of Bushnell brand with water vision with resolution 8x42x and the taxonomic identification of birds was performed with standard field guides (Peterson and Chalif, 1989; National Geographic Society, 2011). The sampling was carried out at two times: morning (06:00-11:00) and afternoon (17:00-19:00), time intervals where avifauna presents the highest peaks of daytime activity. Environmental variations (rain and drought) were obtained according to what was reported by the National Meteorological System (Sistema Meteorológico Nacional, SMN), meteorological station \# 15017, Coatepec, for the period of 2019-2020.

The abundance of birds was evaluated with the relative abundance index (RAI, frequencies recorded) proposed by Carrillo et al. (2000). This index was analyzed in EstimateS 9.1.0 (2018), using presence-absence data. 


\section{Effect of phenology (migration-non-migration), seasonality (rainfed-dry), sex and condition variables of the forest on the abundance of birds}

From the frequency databases of the birds and their abundances, a matrix of scenarios was formulated that was analyzed through a generalized linear model (GLM) in the R Statistics software. Before the generation of the GLM, four predicting variables were defined: 1) condition of the forest, 2) seasonality, 3) phenology, and 4) sex of birds registered. The response variable was the frequency of records in each level of variable (Table 1).

Table 1. Predictor variables and levels.

\begin{tabular}{l|ll}
\hline \multicolumn{1}{c|}{ Predictor variables } & \multicolumn{1}{c}{ Levels } \\
\hline \multirow{2}{*}{ Condition forest } & 1) & Semi-preserved \\
& 2) & Disturbed \\
\hline \multirow{2}{*}{ Seasonality } & 1) & Rainfall \\
& 2) & Dry \\
\hline \multirow{2}{*}{ Phenology } & 1) Migratory \\
\hline \multirow{2}{*}{ Sex } & 2) & No migratory \\
& 1) & Male \\
\hline
\end{tabular}

The GLM model was analyzed with a Poisson distribution, because the data refers to absolute frequencies. The function of link or parametrization was logit, which is used to estimate the expected value of $\mathrm{Y}$ (response variable) as a linear combination of predicting variables. The model entered into the software $\mathrm{R}$ was the following:

$$
\begin{aligned}
\text { Call:gml } \text { (formule } & =\text { Frequency } \sim \text { Sex }+ \text { Phenology }+ \text { Seasonality }+ \text { Forest Condition } \\
& + \text { Sex } * \text { Phenology }+ \text { Sex* Seasonality }+ \text { Sex* Forest Condition } \\
& + \text { Phenology* Seasonality }+ \text { Phenology* Forest Condition } \\
& + \text { Seasonality* Forest Condition }+ \text { Forest Condition } * \text { Seasonality } \\
& * \text { Phenology, family }=\text { poisson }(l o g), \text { data }=\text { Dataset } 2)
\end{aligned}
$$

\section{Validation of the GLM model}

To determine the adjustment of the model, the amount of variance, the standard error, and the $\mathrm{Z}$ value that measures the difference between statistics observed and expected by the model were estimated. In the GLM, these parameters are known as deviance, which is an indicator of the variability of the data. Therefore, both the deviance of the null model and the residual deviance were estimated. The latter measured the variability of the response variable that is not explained by the model. The Akaike Information Criterion (AIC) was also estimated; this index evaluates the adjustment of the model to the data, as well as the complexity of the model. With smaller AIC, there is better adjustment. The AIC is very useful to compare similar models with different degrees of complexity or equal models (same variables) but with different link functions. 


\section{RESULTS AND DISCUSSION}

A total of 527 individuals were found in both zones $(\mathrm{CPOF}=304 ; \mathrm{DPOF}=223)$. In CPOF, 58 individuals of migratory birds and 246 individuals of resident birds were registered, and in DPOF 49 of the individuals corresponded to migratory birds and 174 to resident birds. In Monte Tláloc, according to NOM-059, four species were found that are classified as under Special Protection and two as Threatened. According to the UICN, two species under some threat were found in the study area; one of them in the category of Vulnerable and the other as Almost Threatened; likewise, five endemic species were found.

Seasonally, it was observed that the higher number of individuals from bird species was found in the dry season in CPOF (53\%) and in DPOF (59\%) in the rainy season. Ramírez-Albores (2013) reported similar results in the municipality of Nanacamilpa, Tlaxcala, which is located at a distance of less than $20 \mathrm{~km}$ from Monte Tláloc. This author also mentions an increase of bird diversity in conserved pine forests. The Relative Abundance Index (RAI) of the birds recorded in CPOF suggests that the species with lower presence in the study zone was Aphelocoma ultramarina (0.002) and in higher proportion Empidonax sp. (0.13) (Figure 3), compared to DPOF that was Colaptes auratus (0.003) and Ptiliogonys cinereus (0.23) with higher appearance (Figure 4). It is important to point out that the abundances of all the species were not graphed, and only those of the most representative were chosen for both sites.

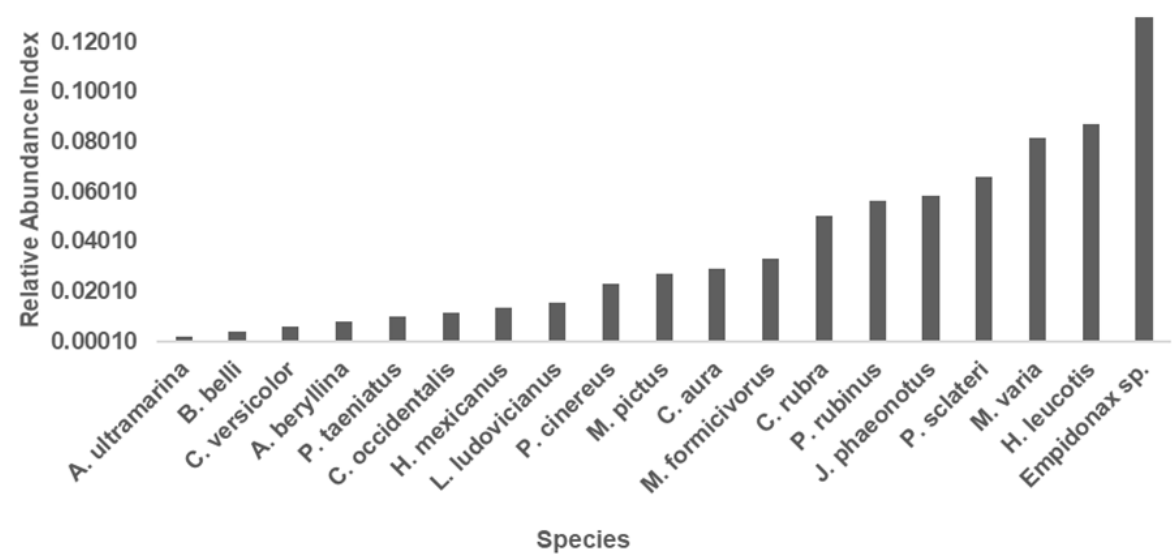

Figure 3. Relative Abundance Index of bird species in the semi preserved Pine-Oak Forest of Monte Tláloc.

Regarding the sex of the individuals present in each of the forest conditions, females predominated in CPOF (53\%) and males in DPOF (52\%).

In general the females presented the highest number of individuals in both conditions $(n=268)$. One of the main reasons why more females were found in the CPOF condition is the possibility that the birds in this condition increase their reproductive success; for example, Huhta (1996) studied the effect of the plot size of pine forest, presence of human disturbances in the use of nests by the pied flycatcher (Fidecula hypoleuca) in a pine forest of similar conditions than those in Monte Tláloc. This author 
found that the nests were more preyed upon in neighboring landscapes or immerse in agricultural fields where predators of this species predominate, while in forest landscapes predation also happened in felled places where the nests were more visible. The more open forests and with low forest density are used for the pied flycatcher, where the availability of food is lower.

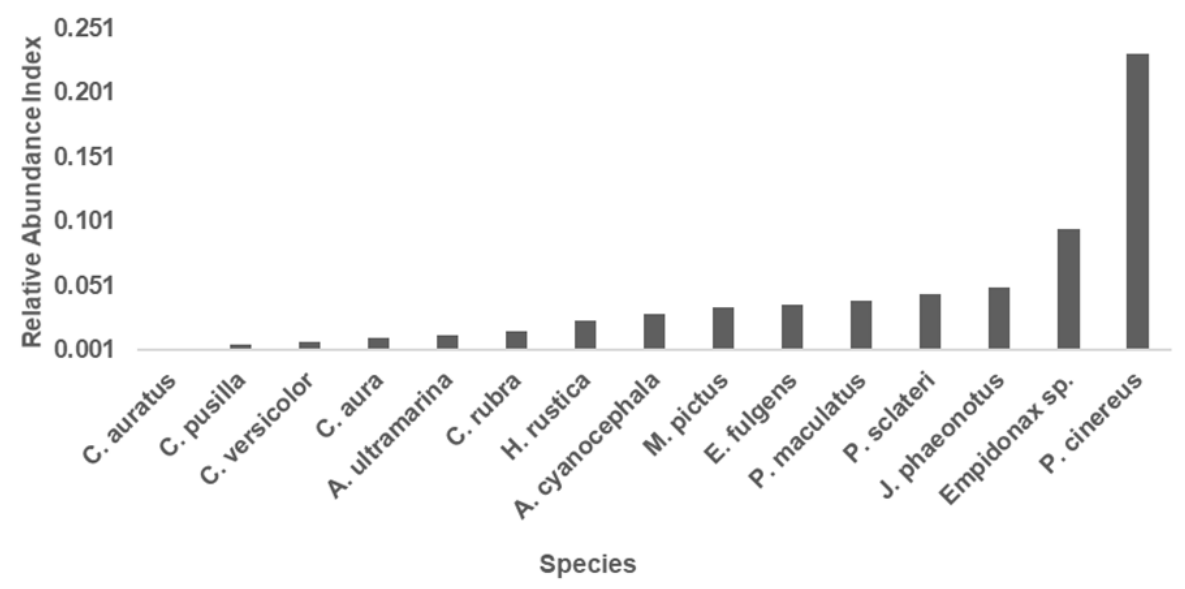

Figure 4. Relative Abundance Index of bird species in the disturbed Pine-Oak Forest of Monte Tláloc.

The Generalized Linear Model suggests that the forest condition is significantly related with the frequency of bird species. For example, the semi-conserved condition had a higher presence of these and at the same time obtained higher number of females than males, so the forest condition also influenced the sex of the avifauna present (Table 2). The GLM indicated that the variables phenology (Residents) and forest condition (Semi-conserved) increase the probability of finding a higher abundance of species. The seasonality variable (Rains) increases their abundance. All the interactions were significant, which indicates that phenology, seasonality, forest condition and sex have a relationship with bird abundance (Table 2). The model explained a high total deviation $(84.9 \%)$ and that $15.1 \%$ of the variance that was not explained by the model correspond to other variables of the ecosystem that were not evaluated in this study; the value of AIC obtained was 116.5.

The number of bird species found in both forest conditions suggests that the degree of disturbance is not a key factor for their presence, given that the environmental and structural conditions of the habitat in a spatial context determine their correct biological-ecological functioning (Armstrong and Nol, 1993; Bó et al., 2007; Mateo et al., 2011; García-Quintas, 2015).

Connell (1978) in his hypothesis of the intermediate disturbance mentions that the disturbances can cause space-time fluctuations in the local and regional biological diversity; in contrast with conserved zones, which can increase the establishment of positive ecological interactions (generalist species) and negative (specialist species) in the use of the habitat. This argument explains why the abundance of species was mostly 
specialist in the semi-conserved pine-oak forest; on the contrary, in the disturbed forest the highest presence of birds was the generalist species.

Table 2. Generalized Linear Model for the two conditions of semi-preserved and disturbed forest, considering only the variables that were significant as a function of the abundance of birds.

\begin{tabular}{l|c|c|c|c}
\multicolumn{1}{c|}{ Variables: } & Estimate & Standar error & $\mathbf{Z}$ & Significance \\
\hline (Intercept) & -1.5766 & 0.8172 & -1.929 & 0.053696. \\
\hline Phenology (Migratory/Resident) & 2.1101 & 0.3245 & 6.502 & $7.90 \mathrm{e}-11^{* * *}$ \\
\hline Condictions of forest (BPES/BPEP) & 2.428 & 0.5101 & 4.76 & $1.94 \mathrm{e}-06^{* * *}$ \\
\hline Sex (Female/Male) & 0.4773 & 0.2629 & 1.816 & 0.069441 \\
\hline Seasonality (Rainfall/Dry) & 0.7716 & 0.2647 & 2.915 & $0.003555^{* *}$ \\
\hline $\begin{array}{l}\text { Condictions of forest (BPES/BPEP): Sex } \\
\text { (Female/Male) }\end{array}$ & -0.372 & 0.1719 & -2.164 & $0.030455^{*}$ \\
\hline $\begin{array}{l}\text { Phenology (Migratory/Resident): } \\
\text { Condictions of forest (BPES/BPEP) }\end{array}$ & -0.6438 & 0.2013 & -3.198 & $0.001385^{* *}$ \\
\hline $\begin{array}{l}\text { Condictions of forest (BPES/BPEP): } \\
\text { Seasonality (Rainfall/Dry) }\end{array}$ & -0.653 & 0.1745 & -3.743 & $0.000182^{* * *}$ \\
\hline
\end{tabular}

Birds are species with a very broad influence in the ecosystems or habitats that they inhabit, and their presence or absence is related to various spatial and temporal factors (Valdez-Leal et al., 2015). Bird migration is affected by diverse reasons; for example, it is known that the reproductive period responds to the change in the weather (Capllonch et al., 2015; Gordo and Avilés, 2017), which could explain the considerably lower number of migratory species compared to the presence of resident species.

\section{CONCLUSIONS}

This study allowed understanding how the avifauna communities are influenced by natural phenology-seasonality processes and the preference that they have for one of the two types of disturbance conditions of the forest. It was observed that seasonal processes influence the presence of birds (migratory and resident) and that these fauna communities concentrate important species that are found in a category of risk or endemic to the place. These results set the standard to develop techniques for conservation and maintenance of the forests both in Monte Tláloc and in the other neighboring mountains of the Trans-Mexican Volcanic Belt.

\section{ACKNOWLEDGEMENTS}

We thank Colegio de Posgraduados Campus San Luis Potosí and Universidad Autónoma Chapingo for the economic support and for transport to perform this study. We are grateful to Dr. Saúl Ugalde Lezama, Claudio Romero Diaz, Uriel Marcos Rivera, Arturo Morales García, and Abril Pérez García for their support during field work.

\section{REFERENCES}

Almazán-Núñez R. C., Puebla-Olivares F., \& Almazán-Juárez Á. (2009). Diversidad de aves en bosques de pino-encino del centro de Guerrero, México. Acta Zoológica Mexicana 25(1), 123-142. 
Armstrong, A.R. \& Nol, E. (1993). Spacing behavior and reproductive ecology of the Semipalmated Plover at Churchill, Manitoba. Wilson Bull 105 (3), 455-464.

Bó, M. S., Baladrón A. V., \& Biondi L. M. (2007). Ecología trófica de Falconiformes y Strigiformes: tiempo de síntesis. El Hornero 22(2), 97-115.

Bolaños-González, Y., Bolaños González, M. A., Paz Pellat, F., \& Ponce Pulido, J. I. (2017). Estimación de carbono almacenado en bosques de oyamel y ciprés en Texcoco, Estado de México. Terra Latinoamericana, 35, 73-86.

Capllonch, P., Alderete, C. A., Aráoz, R., Barboza, E., Mamaní, J. C., Ortiz, D., ... \& Soria, K. (2015). Observaciones y capturas de aves poco conocidas en el norte de Argentina. Nuestras Aves 60, 76-82.

Carrillo E., Wong G., \& Cuarón A. D. (2000). Monitoring mammal populations in Costa Rican protected areas under different hunting restrictions. Conservation Biology, 14(6),1580-1591.

Connell, M. L. (1978). Diversity in tropical rain forests and coral reefs. Science 199, 1302-1310.

Cueto, V., Jahn, A. E., Tuero, D. T., Guaraldo, A. C., Sarasola, J. H., Bravo, S. P., ... \& Jiménez, J. E. (2015). Las aves migratorias de América del Sur. Nuevas técnicas revelan información sobre su comportamiento. Asociación Civil Ciencia Hoy 24, 19-25.

Díaz-Bohórquez, A. M., Bayly, N. J., Botero, J. E., \& Gómez, C. (2014). Aves migratorias en agroecosistemas del norte de Latinoamérica, con énfasis en Colombia. Ornitología Colombiana 14, 3-27.

García-Quintas, A. (2015). Descripción de las colonias reproductivas de aves acuáticas en el Parque Nacional Jardines de la Reina, Cuba/Description of the waterbirds reproductive colonies in the National Park Jardines de la Reina, Cuba. Revista Cubana de Ciencias Biológicas 4. 29-35.

Gordo, O., \& Avilés, J. M. (2017). El valor de los estudios a largo plazo en la ecología del comportamiento. Ecosistema 26, 21-31.

López-Segoviano, G., Díaz-Verduzco, L., Arenas-Navarro, M., \& del Coro Arizmendi, M. (2019). Diversidad estacional de aves en una región prioritaria para la conservación en el centro oeste de la Sierra Madre Occidental. Revista Mexicana de Biodiversidad 90, 1-16.

Mateo, R. G., Felicísimo, Á. M., \& Muñoz, J. (2011). Modelos de distribución de especies: Una revisión sintética. Revista Chilena de Historia Natural 84, 217-240.

National Geographic Society (2011). Field guide to the birds of North America. Fourth edition. National Geographic Society, Washington, D.C. 480 p.

Odum, E. P., \& Warren, G. W. 2006. Fundamentos de Ecología. 5a. Edición. Thompson. México. 639 p.

Peterson R. T. \& Chalif E. L. (1989). Aves de México. Guía de campo. Editorial Diana. México, D. F. 473 p.

Ralph C. J., Geupel G. R., Pyle P., Martín T. E., DeSante D. F. \& Milá, B. (1996). Manual de métodos de campo para el monitoreo de aves terrestres. Department of Agriculture and Forest Service. USA. 46 p.

Ramírez-Albores, J. E. (2013). Riqueza y diversidad de aves de un área de la Faja Volcánica Transmexicana, Tlaxcala, México. Acta Zoológica Mexicana, 29(3), 486-512.

Romero-Díaz, C., Ugalde-Lezama, S., Tarango-Arámbula, L. A., Ruíz-Vera, V. M., Marcos-Rivera, U., \& Cruz-Miranda, Y. (2018). Coexistencia y segregación trófica en aves insectívoras de un bosque templado con tres elevaciones. Ecosistemas y Recursos Agropecuarios 5, 477-489.

Shelford, V.E (1913). Comunidades de animales en las zonas templadas de América: como se ilustra en la región de Chicago: un estudio en ecología animal (n. 5). Prensa de la Universidad de Chicago. 368 p.

Valdez-Leal, J. D. D., Pacheco-Figueroa, C. J., Méndez-López, E., Rangel-Ruíz, L. J., Moguel-Ordoñez, E. J., Arriga-Weiss, S. L., \& Luna-Ruíz, R. D. C. (2015). La comunidad de las aves en tres hábitats de la planicie de Tabasco, México. Agroproductividad 8(5), 69-73.

Villanueva-Díaz, J., Vázquez-Selem, L., Gómez-Guerrero, A., Cerano-Paredes, J., Aguirre-González, N. A., \& Franco-Ramos, O. (2016). Potencial dendrocronológico de Juniperus monticola Martínez en el monte Tláloc, México. Revista Fitotecnia Mexicana 39(2), 175-185. 